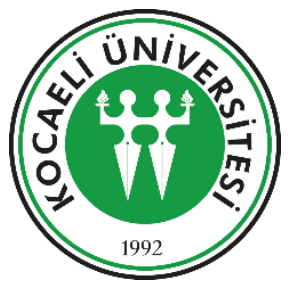

Kocaeli Üniversitesi Sağlık Bilimleri Dergisi

Original Article / Özgün Araştırma

http://dergipark.gov.tr/kusbed

\title{
CATCH-UP GROWTH WITH ENTERAL NUTRITION SUPPORT IN CHILDREN WITH CONGENITAL HEART DISEASE
}

\author{
DOĞUMSAL KALP HASTALIĞI NEDENIYYLE BÜYÜME GERILİ̆Ğ OLAN BEBEKLERDE ENTERAL \\ BESLENME ILE BÜYÜME TAKIBBI
}

\author{
@(i)Alev Arslan ${ }^{*}$ \\ ${ }^{1}$ Baskent University, Faculty of Medicine, Department of Pediatrics, Division of Pediatric Cardiology, Adana, Turkey \\ ORCID ID: Alev Arslan: 0000-0003-4444-0027 \\ *Corresponding Author/Sorumlu Yazar: Alev Arslan, e-mail / e-posta: alevkiziltas@ gmail.com \\ Received / Geliş Tarihi: 23.07.2019 \\ Accepted / Kabul Tarihi: 02.09.2019 \\ Published / Yayım Tarihi: 06.09.2019
}

\begin{abstract}
Objective: Malnutrition has long been recognized as a common systemic consequence of congenital heart defects. Nutritional support with higherconcentration formulas is needed. The aim of this study was to evaluate feeding and growth pattern in malnutrition due to congenital heart defect. Methods: Sixty-one infants (41 asyanotic and 20 cyanotic) with congenital heart disease, who were supported with an enteral nutrition product because of malnutrition and followed in terms of growth development until 24 months of age were evaluated retrospectively. After malnutrition was detected, an energy intake of 140-150 kcal/kg/day was provided by supplemental enteral nutrition product until surgical or invasive interventional correction was applied. Anthropometric measurements, taken at three-month intervals were calculated according to World Health Organization data.

Results: According to results at month 24, 17 patients had mild malnutrition, 4 patients had moderate malnutrition, and 1 had severe malnutrition. Malnutrition was detected in $36 \%$ of all patients. In the acyanotic group, as soon as congestive heart failure started at the $6^{\text {th }}$ week, the growth has regressed. There was an increase in the curve two months after corrective surgery/catheter intervention. The height curves were parallel and elevated in both groups after month 3 and no statistically significant difference was found between the groups at month 24 Weight curves were found to be significantly lower, especially in complex cyanotic patients with palliative surgery.

Conclusion: Malnutrition prevalence has decreased but continued in both groups despite enteral nutrition support. Especially in cyanotic heart diseases, the continuation of hypermetabolic status and higher caloric support is needed with close monitorization of malnutrition.
\end{abstract}

Keywords: Congenital heart defects, malnutrition, enteral nutrition

$\ddot{\mathbf{O z}}$

Amaç: Malnütrisyon, doğumsal kalp hastalıklarında sık saptanan bir sorundur. Bu hasta grubunda daha yüksek kalori içerikli beslenme ürünleri gerekmektedir. Bu çalışmada doğumsal kalp hastalığı olan malnütrisyonlu bebeklerde beslenme ve büyüme paterni değerlendirilmesi amaçlanmıştır. Yöntem: Yenidoğan döneminde doğumsal kalp hastalığı tanısı alıp malnütrisyon nedeniyle enteral beslenme ürünü kullanılan ve 24 aylık olana kadar düzenli büyüme-gelişme takibi yapılan 61 bebek (41 asiyanotik ve 20 siyanotik) retrospektif olarak incelendi. Malnütrisyon saptandıktan sonra, cerrahi veya invaziv girişimsel düzeltme uygulanana kadar enteral beslenme ürünü takviyesi ile $140-150 \mathrm{kcal} / \mathrm{kg} / \mathrm{gün}$ 'lük enerji alımı sağlanmıştı. Üç aylık aralıklarla alınan antropometrik ölçümler Dünya Sağlık Örgütü verilerine göre hesaplandı.

Bulgular: Tüm hastaların 24. ay sonuçları değerlendirildiğinde 17 hastada hafif derecede malnütrisyon, 4 hastada orta derecede malnütrisyon, 1 hastada ağır derecede malnütrisyon mevcuttu. Malnütrisyon, tüm hastaların \%36'sında saptandı. Asiyanotik grupta özellikle 6. haftada konjestif kalp yetersizliğinin başlamasıyla birlikte büyüme eğrisinde gerileme olduğu, cerrahiden/kateter girişiminden iki ay sonra büyüme eğrisinde artma olduğu saptandı. Boy eğrileri üçüncü aydan sonra her iki grupta paralel ve yükselme yönünde idi. Yirmi dördüncü ay ölçümlerinde ise iki grup arasında boy açısından istatistiksel fark saptanmadı; ancak malnütrisyon takibinde boya göre ağırlık eğrileri özellikle tüm düzeltme olamayan kompleks siyanotik hastalarda anlamlı olarak daha düşük saptandı.

Sonuç: Enteral beslenme desteğine rağmen her iki grupta da malnütrisyon devam etmiştir. Özellikle siyanotik kalp hastalıklarında hipermetabolik durumun devam etmesi daha yüksek kalori ihtiyacı gerektirir ve malnütrisyon yakından takip edilmelidir.

Anahtar Kelimeler: Doğumsal kalp hastalı̆̆ı, malnütrisyon, enteral beslenme 


\section{Introduction}

Malnutrition and growth retardation are common problems in children with congenital heart disease due to higher energy requirements but lower energy intake. ${ }^{1}$ Malnutrition has been reported in $25-90 \%$ of infants with congenital heart disease, and is one of the most important causes of morbidity and mortality, especially in the perioperative period. ${ }^{2,3}$ Hospitalization, gastroenteritis, upper respiratory tract infections, somatic growth retardation and later cognitive dysfunctions are more common in children with malnutrition. The etiology is often multifactorial and includes hypermetabolic status, inadequate caloric intake, swallowing dysfunction, malabsorption, gastroesophageal reflux, gastrointestinal system immaturity, and genetics.

The aim of this study was to evaluate growth failure and catchup growth in infants with congenital heart disease, who has been supported with enteral nutrition due to malnutrition.

\section{Methods}

A total of 61 infants with malnutrition due to congenital heart disease (CHD) (20 cyanotic and 41 acyanotic), who were diagnosed at newborn period and followed up for least two years postnatally, were enrolled in a retrospective cohort in a university hospital. The patients were grouped as acyanotic (group 1) and cyanotic (group 2). Syndromic infants were excluded from the study (four with Down syndrome, three with DiGeorge syndrome). Weight and height were measured. Nutritional status was assessed by z-scores of weight for age, height for age, and weight for height, adopting the Centres for Disease Control and Prevention 2000 curves as reference. ${ }^{4}$ Nutritional status was assessed indirectly according to the percentage of actual weight to ideal body weight for length, which demonstrates degree of malnutrition and Waterlow's criteria, which indicates the duration of malnutrition (Table $1) .^{5}$

Table 1. Classification of protein energy malnutrition by Waterlow ${ }^{5}$

\begin{tabular}{l|c}
\hline $\begin{array}{l}\text { Degree of Protein Energy } \\
\text { Malnutrition }\end{array}$ & Weight for Height $(\boldsymbol{\%})$ \\
\hline Normal & 90 \\
Mild & $80-90$ \\
Moderate & $70-80$ \\
Severe & $<70$ \\
\hline
\end{tabular}

The visits were performed by the same pediatric cardiologist in the newborn period, in the first month, the third month, and then at every three-month intervals up to two years. All mothers were encouraged to breastfeed for at least six months. High energy, nutritionally complete infant formula $(1 \mathrm{kcal} / \mathrm{mL})$ $(130-150 \mathrm{kcal} / \mathrm{kg} / \mathrm{day}$ caloric intake) was administered to infants with or at risk of faltering growth from the first month till 24 months of age Patients were supported with enteral nutrition at least three months after corrective surgery and up to the age of 24 months for palliative surgery or ongoing risk of faltering growth. Interventional catheter procedures, surgical procedures and spontaneous recoveries were recorded. Enteral nutrition product is a nutritionally complete, energy dense $(1 \mathrm{kcal} / \mathrm{mL})$ product, ready to use for the dietary management of infants from the birth up till 18 months of age or $9 \mathrm{~kg}$ of body weight with faltering growth, or who have increased nutritional or fluid restriction requirements. It is suitable as sole source of nutrition and contains galactooligosaccharides/ fructooligosaccharides, nucleotides and a unique fat blend that contains long-chain polyunsaturate long-chain polyunsaturated fatty acids.

\section{Statistical Analysis}

Statistical analysis was performed using IBM SPSS Statistics (Version 16.0, SPSS Inc., Chicago, IL, USA). Comparisons between groups were applied using the Mann Whitney U Test for the data not normally distributed. Categorised variable compared in group with Chi square test.

\section{Results}

Diagnosis of patients was summarized in Table 2.

Table 2. Congential heart defects

\begin{tabular}{l|c}
\hline Acyanotic & $\mathbf{n = 4 1}$ \\
\hline Ventricular Septal Defect & 26 \\
Ventricular Septal Defect+Coarctation of Aorta & 3 \\
Ventricular Septal Defect+Patent Ductus Arteriosus & 2 \\
Atrioventricular Septal Defect & 4 \\
Patent Ductus Arteriosus & 6 \\
\hline Cyanotic & $\mathbf{n = 2 0}$ \\
\hline Tetralogy of Fallot & 3 \\
Tetralogy of Fallot+Pulmonary Atresia & 2 \\
Tetralogy of Fallot+Absent Pulmonary Valve & 1 \\
Transposition of Great Arteries & 5 \\
Double Outlet Right Ventricle+Transposition of Great & 2 \\
Arteries & 2 \\
Double Outlet Right Ventricle+Pulmonary Stenosis & 3 \\
Tricuspid Atresia & 1 \\
Total Abnormal Pulmonary Venous Return Abnormaly & 1 \\
Truncus Arteriosus Type 3 & \\
\hline
\end{tabular}

Invasive procedures and surgeries were summarized as; 43 patient corrective surgery, 7 patient with spontan regression/closure of the defect, 6 transcatheter closure of patent ductus arteriosus and 5 palliative surgery (pulmonar banding for 2 patient with unbalanced atrioventricular septal defect, pulmonary artery banding in newborn period and cava pulmonary anastomosis at $6^{\text {th }}$ month for 3 patient). The median time of procedures was 5.5 months (min 2 weeks-max 18 months). Spontan heart defect regression or closure was detected in 7 patients and nutritional support was discontinued when they reached the appropriate percentile. The birth weight/height percentile values did not differ between the two groups. When the patients were evaluated at 2 years of age, mild malnutrition was detected in 17 patients (14 acyanotic, 3 cyanotic) and moderate malnutrition was detected in 4 patients (3 patients with cava pulmonary anastomosis for univentricular physiology, one operated Double outlet right ventricleperipheral pulmonary stenosis with residual stenosis and severe with faltering growth, or who have increased nutritional requirements and/or require fluid restriction, right heart failure). Severe malnutrition was detected in one patient who had cava pulmonary anastomosis due to tricuspid valve atresia. At the end of the study, $36 \%$ of all patient demonstrated malnutrition. Thirty four percentage of acyanotic group had only mild degree malnutrition. Fourty percentage of cyanotic group had malnutrition with a distribution of $15 \%$ mild, $20 \%$ moderate, $5 \%$ severe degree.

In group 1 , the weight for age percentiles and $\mathrm{z}$ scores decreased significantly in the first 3 months, followed by a 
steep increase, than parallel to group 2 after 1 year of age. At the end of the 24 months no significant difference was detected about the weight for age percentiles/z scores between two groups (Figure 1).

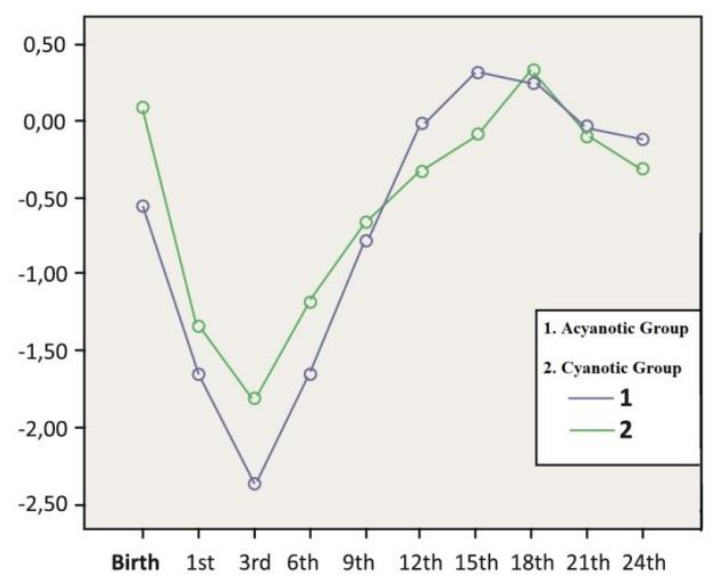

Figure 1. Weight for age $\mathrm{z}$ scores between acyanotic and cyanotic congenital heart disease (blue line; acyanotic group, green line; cyanotic group)

The height for age percentiles and $\mathrm{z}$ scores decreased significantly in the first 3 months, later curve raised parallel in both groups (Figure 2).

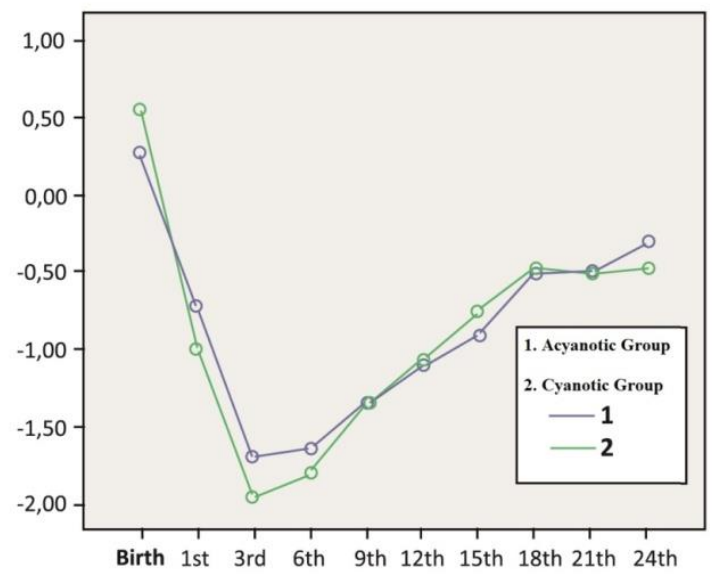

Figure 2. Height for age $\mathrm{z}$ scores between acyanotic and cyanotic congenital heart disease (blue line; acyanotic group, green line; cyanotic group)

The weight for height curves was different between two groups. In group 1, weight for height curves were significantly low in the first 6 months, than raised and catched up growth after 9 months old. In group 2, two declines in the weight for height curve detected in the first year period. The first was between 1-3 months and the second was between 3-9 months. Both of the groups had parallel decline in weight for height curves after 18 months (Figure 3).

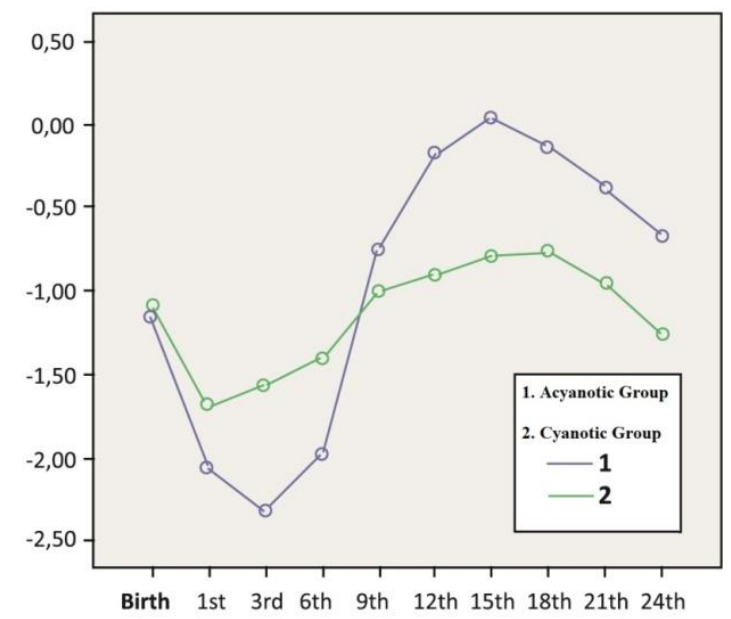

Figure 3. Weight for height $\mathrm{z}$ scores between acyanotic and cyanotic congenital heart disease (blue line; acyanotic group, green line; cyanotic group)

\section{Discussion}

Infants with congenital heart defects often display faltering growth due to elevated nutritional requirements, poor intake and intolerance of feeding with malabsorption and maldigestion. As a result, their nutritional management can be extremely challenging and enteral nutritional support is required.

Breast milk is considered the ideal nutrition for all newborns because of proven nutritional, immunological and interpersonal (mother-child) benefits. Furthermore, caloric intake of mother's milk may not be enough to support the growth of infants affected by congenital heart disease. The American Society for Parenteral and Enteral Nutrition (ASPEN) provides recommendations for critically ill children receiving protein intake $(0-2$ years, $2-3 \mathrm{~g} / \mathrm{kg} / \mathrm{d}){ }^{6}$ Enteral nutrition exerts beneficial effects on intestinal trophism, intestinal secretion, intestinal translocation, and other functions. $^{7}$

Malnutrition status of patients is important in terms of mortality risk in perioperative period. In the postoperative period, $120-140 \mathrm{kcal} / \mathrm{kg}$ caloric intake is necessary for catch up growth. Malnutrition results in reduced muscle function, poor wound healing, and impaired immunity which may increase postoperative morbidity and mortality. ${ }^{8}$ Children with congenital heart disease are reported to present catch-up growth within 3-12 months after surgery in both developed and developing countries. ${ }^{9-11}$ Patients were supported with enteral nutrition at least 3 months after corrective surgery and up to 24 months old for palliative surgery or ongoing risk of faltering growth in the current study.

The birth weight/height percentile values did not differ between the two groups, but the weight curve showed a significant decrease in the acyanotic group after 1 month. This condition was thought to be due to decrease in pulmonary vascular resistance, increased amount of left-right shunt, initiation of decongestive therapy, and increased caloric requirement due to congestive heart failure. A marked increase in total energy expenditure relative to resting energy expenditure has been reported in 3- to 5-month-old infants with ventricular septal defect. ${ }^{12}$ In the current study, weight for height percentile curve in group 1 was significantly low in the first 6 months, then raised and caught up growth after 9 months old. 
Height curves showed a sharp decline in the first 3 months, then a parallel increase in both groups. At the age of 24 months, there was no statistical difference between two groups' height percentile and z scores. However, weight for height curves was found to be significantly lower especially in patients who had had palliative surgeries or ongoing heart failure. In these patients enteral nutrition support was continued until the age of 24 months due to malnutrition.

The energy used for growth is high in the first 3 months of life (45\% of total energy) and decreases as the child grows older. ${ }^{13}$ Surgeries and heart failure dynamics due to congenital heart defects cause important energy loss especially in the first 3 months. It is important to start nutritional support in these patients before malnutrition develops.

At the end of 2 years, most of the cyanotic patients had mild to moderate malnutrition. Especially in patients with single ventricular physiology or with hemodynamically significant residual defect, malnutrition was moderate. Chronic hypoxemia has been shown to contribute to anorexia, feeding factors, and frequent infections of upper and lower respiratory tracts and may affect the digestive tract by decreasing enzyme activities. In recent animal models of cyanotic heart disease, decreased levels of IGF-1 were associated with chronic hypoxemia, and growth failure. ${ }^{14}$ In group 2, two declines in weight for height percentiles reflected two palliative surgery times in the first year period. After 18 months, both of the groups had declines in weight for height curves, which should be explained by parenteral discontinuation of enteral nutrition support. The continuation of higher caloric enteral nutritional support $(1.5 \mathrm{kcal} / \mathrm{kg})$ with different taste options may be more attractive and beneficial for patients older than 1 year old.

In conclusion, feeding difficulties and growth failure are lifelong problems in children with congenital heart diseases, particularly in those with univentricular hearts. Enteral nutrition support should begin after the newborn period in patients who have increased nutritional requirements and/or require fluid restriction. Growth failure in infancy can have an impact on postoperative outcomes and long-term neurodevelopment. Although surgical repair of heart defects in the neonatal period usually results in weight gain within a few months, longitudinal growth and head circumference often experience delay for a year or more.

\section{Acknowledgments}

None declared

\section{Conflict of Interest}

None declared

\section{Compliance of Ethical Statement}

This study (Grant No: KA9/30) was performed in accordance with the ethical standards approved by the Committee for Scientific Research and Publication Ethics at Baskent University in Ankara, Turkey.

\section{Financial Disclosure/Funding}

None declared

\section{References}

1. Mehta NM, Corkins MR, Lyman B, et al. Defining pediatric malnutrition: A paradigm shift toward etiology-related definitions. J Parenter Enteral Nutr. 2013;37:460-481. doi:10.3389/fendo.2017.00364

2. Argent AC, Balachandran R, Vaidyanathan B, Khan A, Kumar $\mathrm{K}$. Management of undernutrition and failure to thrive in children with congenital heart disease in low-and middle-income countries. Cardiology in the Young. 2017;26:22-30. doi:10.1017/S104795111700258X

3. Nydegger A, Walsh A, Penny DJ, Henning R, Bines JE. Changes in resting energy expenditure in children with congenital heart disease. Eur J Clin Nutr. 2009;63:392-397. doi:10.1038/sj.ejen.1602956

4. Growth charts. Centers for Disease Control and Prevention. http://www.cdc.gov/nccdphp/dnpa/growthcharts/resources/gro wthchart.pdf. Accessed July 24, 2019.

5. Waterlow JC. Classification and definition of protein-calorie malnutrition. $\quad B r \quad M e d \quad J . \quad 1972 ; 3: 566-569$. doi:10.1136/bmj.3.5826.566

6. Mehta NM, Compher C, A.S.P.E.N. Board of Directors. A.S.P.E.N. Clinical Guidelines: nutrition support of the critically ill child. J Parenter Enteral Nutr. 2009;33(3):260-276. doi:10.1177/0148607109333114.

7. Kreymann KG, Berger MM, Deutz NE, et al. ESPEN Guidelines on Enteral Nutrition: Intensive care. Clin Nutr. 2006;25(2):210223.

8. Carmona F, Hatanaka LS, Barbieri MA, et al. Catch-up growth in children after repair of Tetralogy of Fallot. Cardiol Youn. 2012;22(5):507-513. doi:10.1017/S1047951111002009.

9. Radman M, Mack R, Barnoya J. The effect of preoperative nutritional status on postoperative outcomes in children undergoing surgery for congenital heart defects in San Francisco (UCSF) and Guatemala City (UNICAR). J Thorac Cardiovasc Surg. 2014;147(1):442-450. doi:10.1016/j.jtcvs.2013.03.023

10. Eskedal LT, Hagemo PS, Seem E. Impaired weight gain predicts risk of late death after surgery for congenital heart defects. Arch Dis Child. 2008;93(6):495-501. doi:10.1136/adc.2007.126219.

11. Tokel K, Azak E, Ayabakan C, et al. Somatic growth after corrective surgery for congenital heart disease. Turk J Pediatr. 2010;52(1):58-67.

12. Ackerman IL, Karn CA, Denne SC, Ensing GJ, Leitch CA. Total but not resting energy expenditure is increased in infants with ventricular septal defects. Pediatrics. 1998;102(5):1172-1177.

13. Wells JC, Davies PS. Estimation of the energy cost of physical activity in infancy. Arch Dis Child. 1998;78(2):131-136. doi:10.1136/adc.78.2.13.

14. Varan B, Tokel K, Yilmaz G. Malnutrition and growth failure in cyanotic and acyanotic congenital heart disease with and without pulmonary hypertension. Arch Dis Child. 1999;81(1):49-52. doi:10.1136/adc.81.1.49. 